\title{
It all takes time
}

From the first issue of $E T$ in January 1985, our coverage of the language has matched our subtitle, 'the international review of the English language', but for several years I was all too aware that some parts of the world were proving more equal than others: it was far easier to get material and views from Asia, Europe and North America than from Africa, Australasia, the Caribbean, and Latin America.

This does not mean that issues relating to such places were not being mentioned, but in the early years there was a dearth of contributors directly from such places. And it has taken time to get them. Observant readers, however, will have noticed that in the last two years the gaps have grown smaller and that $E T$ is much more evenly international than it was in its first three years.

In this issue, there are contributions by Paul Christophersen (Danish), Jean-Marc Gachelin (French), myself (Scottish), Behzad Kasravi (Iranian, living in California), Ibrahim Gyasi (Ghanaian), Thomas Clayton (American, living in Japan), Ruth Wajnryb (Australian), Frank Palmer, Brian Howes, Brian White, and Raymond Chapman (English), P. D. Tripathi (Indian, working in Ethiopia and writing about Zambia), Judith Cowan (Canadian), Denise Murray (American), Laurence Urdang (an American who 'commutes' to England), Jack Miller (American), Geoffrey Hughes (South African), and Don Long (New Zealand).

Something else that can take time is pursuing and renewing subscriptions and posting off copies of ET to subscribers. Some readers served by the Press in Cambridge have recently been having difficulty taking out or renewing subscriptions. Cambridge Journals are very much aware of this and wish to apologize to readers who may have been affected and have not for any reason received a personal letter of apology and explanation from them.

Many thousands of subscriptions are processed in January each year and the Press constantly seeks better ways of doing this. Although an improved computer system is being installed, there have been serious problems that have stretched staff to their limit and led to delays and at times confusion.

Cambridge Journals regretfully acknowledge that this year some people have had to wait an unacceptably long time for $E T$. The Press greatly appreciates the patience and goodwill that readers have shown.

Tom McArthur

The editorial policy of English Today is to provide a focus or forum for all sorts of news and opinion from around the world. The points of view of individual writers are as a consequence their own, and do not reflect the opinion of the editorial board. In addition, wherever feasible, ET leaves unchanged the orthography (normally British or American) and the usage of individual contributors, although the editorial style of the magazine itself is that of Cambridge University Press.

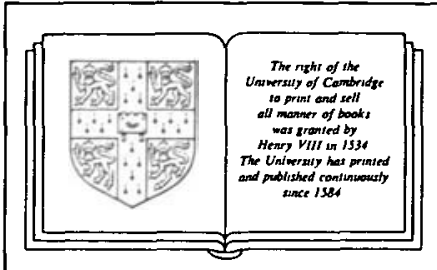

(C) Cambridge University Press 1990. No contents may be reproduced by any means without the permission of Cambridge University Press.

English Today (ISSN 0266-0784) is a quarterly. ISBN 0521399092

UNITED KINGDOM:

Publisher: Cambridge University Press, Edinburgh Building, Shaftesbury Road, Cambndge CB2 2RU. Telephone (0223) 312393

Subscriptions: the current annual subscription price for four issues for libraries and institutions is $£ 34$ in UK, £37 elsewhere; $£ 17$ for individuals E13 for students and the retired; airmail \&8 per year extra. Apply to Paul Driver.

Promotion: write to Vicky Shipton at the above address.

Advertising Sales: write to Anita Hebblethwaite at the above address.

USA AND CANADA:

Publisher: Cambridge University Press, 40 West 20th Street, New York, NY 10011. Telephone (212) 9243900.

Subscriptions: the current annual subscription price in USA and Canada for libraries and institutions is $\$ 59$; $\$ 27$ for individuals; $\$ 20$ for students and the retired; Copies are arr-freighted to New York to arrive with minimum delay. Apply to Janet DeSandre.

Promotion: write to Harry Florentine at the above address.

Advertising Sales: write to Michelle Alumkal at the above address.

Second class postage paid at New York, NY and at additional mailing offices.

POSTMASTER: send address changes in USA and Canada to English Today, Cambridge University Press, 110 Midland Avenue, Port Chester, New York, NY 10573.

Letters to the Editor: write to Dr Tom McArthur, Editor, English Today, 22-23 Ventress Farm Court, Cherry Hinton Road, Cambridge CB1 4HD, UK.

Typeset by Goodfellow \& Egan. Printed in Great Britan at the University Press, Cambndge 